\title{
Histone H2B Gene
}

National Cancer Institute

\section{Source}

National Cancer Institute. Histone H2B Gene. NCI Thesaurus. Code C154300.

A gene encoding the core histone protein histone H2B. 